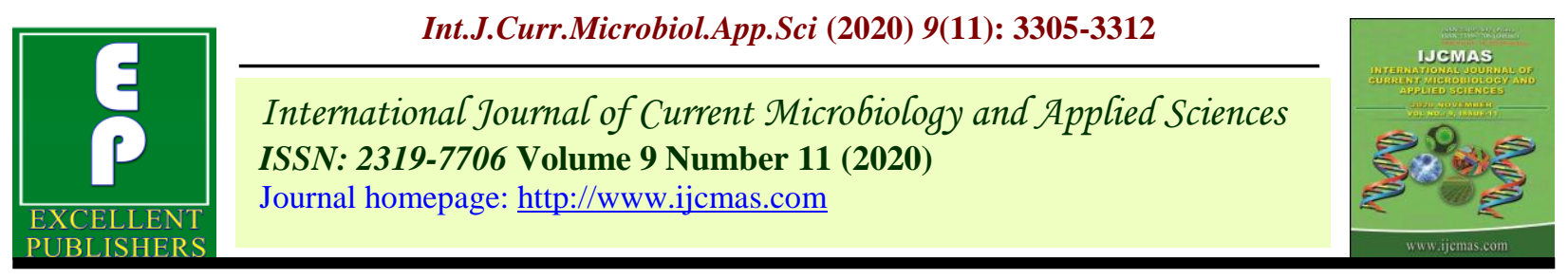

Original Research Article

https://doi.org/10.20546/ijcmas.2020.911.395

\title{
Nutritional and Sensory Evaluation of Jackfruit Rind Powder Incorporated with Cookies
}

\author{
H. N. Ramya*, S. Anitha and A. Ashwini \\ Department of food Science and technology, Agriculture College, Hassan, India \\ *Corresponding author
}

\section{A B S T R A C T}

\begin{tabular}{l} 
Ke y w o r d s \\
$\begin{array}{l}\text { Physico-chemical, } \\
\text { Sensory analysis, } \\
\text { High fibre cookies, } \\
\text { Jackfruit rind }\end{array}$ \\
\hline Article Info \\
$\begin{array}{l}\text { Accepted: } \\
22 \text { October } 2020 \\
\text { Available Online: } \\
10 \text { November } 2020\end{array}$ \\
\hline
\end{tabular}

\begin{abstract}
The main objectives of this study were to develop jackfruit-based high fiber cookies by utilizing jackfruit rind flour in cookies formulation, and to characterize physical properties of produced high fibre cookies. Jack fruit rind pieces were undergone few soaking and washing steps prior to get dried and milled. Obtained Jackfruit rind flour (JRF) was incorporated into wheat flour (WF) in three different ratios $(5,10$ and $15 \%)$ to produce partially substituted wheat flour (WF) with JRF. Cookies based on WF substituted with $5 \%$ JRF $\left(\mathrm{T}_{2}\right)$, cookies based on WF substituted with $10 \%$ JRF $\left(\mathrm{T}_{3}\right)$ and cookies based on WF substituted with $15 \% \mathrm{JRF}\left(\mathrm{T}_{4}\right)$ were undergone proximate, physical and sensory analysis. The incorporation of JRF caused significant influence on sensory, physical and chemical attributes. Increasing the level of JRF incorporated into WF caused an increase in darkness of cookies samples, and decrease in their spread ratio compared to the control. Cookies samples substituted with 5\% JRF had the highest mean scores of overall acceptances.
\end{abstract}

\section{Introduction}

Jack fruit (Artocarpus heterophyllus) is one of the popular fruits in India. It considered to be the Poor man's food (Prakash et al., 2009). Jackfruit is an underutilized fruit crop. Jackfruit rinds are normally disposed as wastes by food industries and vendors. Owing to its wide variety of applications, a major amount of peel (which constitutes $\sim 59 \%$ of the ripe fruit) is discarded as waste. Inbaraj, et al., 2006.The roughly annual jackfruit peel manufacture is estimated to be $2714-11,800$ $\mathrm{kg}$ per tree. These residues create a potential threat as a waste product. Appropriate ways to convert these wastes into value-added merchandise by means that of by-product recovery will serve the twin purpose of environmental protection and value addition. Pectin is a valuable by-product that may be secured from these fruit wastes. These rind have a great potential as a source of many important nutrients.

Jackfruit rind includes perianths of unfertilised fruits, so, it is generally used to produce syrups and jellies due to its good basis of pectin. Rinds along with other waste parts of the fruits are utilized as a nourishing feed for livestock.

In the processing of the edible portion of jack 
fruit into preserved products, the skins, peels and rind are left as a waste material. These wastes constitutes about $45 \%$ of the total fruit weight and found to be a fairly good source of pectin (Jain and Lal 2002). The use of Jackfruit rind powder in the manufacture of value-added food products such as cookies, biscuits, muffins and breads may profit to consumers and industries

Reza Felli, Tsjul Aris Yang and Wahidu Zzaman showed interest towards beneficial products and improved to healthy bread by addition of ingredients high in protein, dietary fibre and low in calorie. Incorporation of Jack fruit rind powder in bread improved functional properties of flour such as oil holding capacity, water holding capacity. According to reports by Galisteo (2008), high dietary fibre intake has been proved to be beneficial for human health with reducing effect on colonic cancer, income, employment, opportunities and health benefits (Haq, 2002).

Wheat Flour provides the structure in baked goods. Wheat flour contains proteins that interact with each other when mixed with water, forming crumbly texture. It contains low gluten.

The protein content of a flour affects the strength of a dough. The different wheat flour types contain varying amounts of the gluten forming proteins.

Milk contains dozens of other types of proteins beside the caseins. They are more water soluble than the caseins and do not form large structures. Because these proteins remain suspended in the whey, left behind when the caseins coagulate into curds, they are collectively known as whey proteins. Whey proteins make up approximately twenty percent of the protein in milk, by weight. $\beta$ lactoglobulin, $\alpha$-lactalbumin and proteose- peptone are the most common whey protein by a a large margin.

Incorporation of Jackfruit Rind powder (JRP) to make a bakery products might be treated as a source of dietary fiber, value added food, income generation and health benefits for the communities. Moreover the use of Jackfruit rind powder (JRP) is also an environment friendly sustainable technology since it could resolve the solid waste disposal delinquent of residues. Therefore, the aim of the present research work was to utilise the jackfruit rind as dietary fiber ingredients in bread and to determine the chemical and functional properties of the prepared cookies. Hence, the study was undertaken with jack fruit rind with following specific objectives include to determine the nutrient composition of jack fruit rind flour. To standardise the production of cookies made from wheat flour blended with jack fruit rind flour. To determine the physical and nutrient composition of composite cookies and also to evaluate the sensory properties of composite cookies.

\section{Materials and Methods}

The experiment was conducted to study the effect of incorporation of different levels of Jack fruit rind flour (JRF) in order to produce good quality cookies. Jackfruits were purchased from local market of Hassan city, Karnataka, India. Remaining Raw materials such as Wheat flour (Maida), Sugar powder, Fat (oil), Baking powder and Milk Powder purchased from local market.

\section{Preparation of jackfruit rind powder}

Jackfruit rind was undergone through several processing steps prior to produce dried jackfruit rind powder. Preparation of jackfruit rind was accomplished according to the technique stated by Feili et al., (2013). Jackfruit rinds were separated from the rest of 
the fruit and were washed with deionised water. After soaking (for $10 \mathrm{~min}$ ) in boiling water and rinsing the ring were seeped for 10 min in a boiling solution sodium bi-sulfite $(0.1 \% \mathrm{w} / \mathrm{w})$ and then rinsed. Another soaking step by using boiling solution (sodium bicarbonate) for 15 min were conducted and jackfruit rind pieces were rinsed three times. Then, convection dryer was used to dry them at $50^{\circ} \mathrm{C}$ for $24 \mathrm{~h}$. The dried samples were powdered using a miller and further sifted over a $355-\mu \mathrm{m}$ mesh screen. The resulted jackfruit rind powder were preserved in containers (airtight plastic) and kept at $4{ }^{\circ} \mathrm{C}$ in a fridge prior to use.

\section{Formulation and preparation of cookies}

The cookies were made in the department of Food Science and technology, College of Agriculture, Hassan using the standard recipe consisting of refined wheat flour $100 \mathrm{~g}$, sugar $50 \mathrm{~g}$, fat $60 \mathrm{~g}$, sodium bicarbonate $0.5 \mathrm{~g}$, custard powder 2 g (Kamaliya et al., 2001). Various ratios of Jack fruit rind flour were used to standardize the cookies. Three variations were prepared $-\mathrm{T}_{1}$ (Standard $100 \%$ wheat flour), $\mathrm{T}_{2}$ (wheat flour $95 \%$ and jack fruit rind flour $5 \%$ ), $\mathrm{T}_{3}$ (wheat flour $90 \%$ and jack fruit rind flour $10 \%$ ), $\mathrm{T}_{4}$ (wheat flour $85 \%$ and jack fruit rind flour 15\%) respectively. The other ingredients such as sugar (50 g), milk powder (15 g), salt (3 g), fat $(50 \mathrm{~g})$ and water $(30 \mathrm{ml})$ was calculated(AACC, 2000). Formulation for cookies preparation is summarized in Table 1. Mixing is followed by moulding, in which the dough is laminated into sheets and moulded into required shapes using different moulds. Moulded cookies were placed on fat greased try and Baked at $150^{\circ} \mathrm{C}$ for $15 \mathrm{~min}$. After baking cookies were Cooled to room temperature and packed in high density poly Ethelene covers for further chemical analysis and sensory evaluation (Fig. 1 and 2).

Sensory evaluation
Sensory evaluation was conducted for the freshly baked cookies by 15 semi-trained panellists consisting of students and staffs (male and female) aged from 25-43 years old from agriculture college, Hassan. The sensory evaluation was conducted in a laboratory under ambient temperature using a 9-point hedonic scale.

Panellists evaluated the sensory properties of the cookies samples based on their degree of like (scale of 1-9) where 9- point hedonic scale with 9 as like extremely and 1 as dislike extremely. The sensory attributes which were evaluated were color, aroma, crispiness, taste and overall acceptability. The panel of 15 semi-trained judges using the mean value of the scores is calculated.

\section{Physico-chemical analysis}

Moisture, protein, total ash, total dietary fibre, fat, Carbohydrates, and energy contents were determined by standard methods (AOAC 2010).

Properties like weight, thickness, diameter and spread ratio of cookies were determined as per the method described by Anu et al, 2015. Spread ratio of cookies was obtained by using the formula dividing the diameter by thickness of the cookies.

\section{Statistical analysis}

Statistical Analysis was done using computer software. The analysis was done by application of ANOVA at 5\% significance level.

\section{Results and Discussion}

Proximate analysis of Ingredients used in cookies

The compositions of commercial wheat flour (WF) and jackfruit rind flour (JRF) are shown in Table 2. According to the obtained results, 
all the parameters were significantly different $(\mathrm{p}<0.05)$. The JRF had a significantly $(p<0.05)$ lower content of crude fat $(0.78$ $\mathrm{g} / 100 \mathrm{~g}$ of dry matter), higher amount of ash $(6.28 \mathrm{~g} / 100 \mathrm{~g}$ of dry matter) and crude fiber $(10.10 \mathrm{~g} / 100 \mathrm{~g}$ of dry matter) than wheat flour. However, it had a lower level of moisture $(10.83 \mathrm{~g} / 100 \mathrm{~g}$ of dry matter), and crude protein $(4.25 \mathrm{~g} / 100 \mathrm{~g}$ of dry matter) and energy (337.26 kcal/100g) than WF. Lower protein content in JRF $(4.25 \mathrm{~g} / 100 \mathrm{~g}$ of dry matter) compared to WF $(11.00 \mathrm{~g} / 100 \mathrm{~g}$ of dry matter) and milk powder $(25.8 \mathrm{~g} / 100 \mathrm{~g}$ of dry matter). Boiling the jackfruit rind pieces in water may cause loosing water-soluble proteins of the final sample (Rodriguez, et al., 2008). On the other hand, higher content of crude fiber in JRF shows that it has the potential to be applied as a high fiber source in bakery products. Generally, since the bran fractions are removed during the milling process of wheat, commercial WF is not known as a rich source of high dietary fiber (Bodroza, et al., 2008).

\section{Sensory analysis}

\section{Scoring system}

9-like extremely 8-like very much 7-like moderately 6-like slightly 5-neither like nor dislike 4-dislike slightly 3-dislike moderately 2-dislike very much 1-dislike extremely.

Table 3 summarized the mean scores of hedonic sensory evaluations for color, aroma, taste, texture, appearance and overall acceptability of cookies samples. As can be seen, substitution of jack fruit rind flour with $5 \%, 10 \%$ and $15 \%$ had a significant effect on all sensory parameters of the cookies samples. The taste and texture were not significantly different in $10 \% \mathrm{JRF}$ and $15 \% \mathrm{JRF}$. However, both of them showed lower scores in taste and texture compared to $5 \% \mathrm{JRF}$ and $\mathrm{T}_{1}$ (control). Generally, addition of JRF had significant effects on sensory attributes and overall acceptability of cookies samples. Addition of JRF caused darker color and denser texture, which at level of 5\% seem acceptable for consumers (Table 3). However, increasing incorporation of JRF to $10 \%$ or $15 \%$ seems to have negative effect on consumer's overall acceptability. For consumers, color of the cookies is one of the important factors in sensory evaluation depending on their perception of cookies type. Average scores of cookies for aroma which can be determined by the sense of smell, was significantly lower in $10 \% \mathrm{JRF}$ and $15 \% \mathrm{JRF}$ compared to $5 \%$ JRF and control which showed addition of JRF more than $5 \%$ has a negative effect on final product in terms of aroma. As shown in Table 3, same trend observed in taste, texture and appearance. However, increase in JRF seems was not acceptable panellists. Therefore, only 5\%JRF received acceptable scores since had an overall acceptability of 9.00.Addition of JRF in formulation of cookies samples significantly affected the textural properties of the product. Hardness of cookies samples were significantly increased by increasing the JRF in their formula from $5 \%$ to $15 \%$. Hardness is mainly attributed to the amylose and amylopectin matrix which contribute to overall bread texture (Schiraldi, 2000).

\section{Physical properties of cookies}

Cookies prepared by incorporation of JRF $5 \%, 10 \%$ and $15 \%$ i.e. $\mathrm{T}, \mathrm{T}_{3}$ and $\mathrm{T}_{4}$ were compared with control (JRF 0\%) i.e $\mathrm{T}_{1}$ respectively and were evaluated for various physical parameters viz., weight, diameter, thickness and spread ratio (Table 4). It is clear from the table that with the incorporation of JRF (5\%), there was a significant decrease in diameter from 3.50 to $3.20 \mathrm{~cm}$ and spread ratio from 583.33 to 457 compared to control. Spread factor is the ratio that depends on the values of the thickness and diameter of the 
cookies. Significant differences occurred on the spread factor of the cookies. Highest spread factor (54.03) was observed in the cookies from $80 \%$ wheat $/ 20 \%$ AYBWEP blend and the lowest value (46.69) was found in $95 \%$ wheat $/ 05 \%$ AYPWEP blend. Results regarding the physical evaluation of the cookies are similar with that reported by $\mathrm{Abu}$ et al., (2007).

There was no significant difference $(p>0.05)$ in the bulk density and thickness of the cookies. The cookies prepared using 80: 20 blends had the higher diameter $(22.53 \mathrm{~cm})$ and spread factor $(54.03 \mathrm{~cm})$ compared to the control (Ade et al., 2012).

Table.1 Formulations Used for the Preparation of Cookies Incorporated with Wheat Flour and Jack Fruit Rind Flour

\begin{tabular}{|l|l|l|l|l|}
\hline Ingredients & $\mathbf{T}_{\mathbf{1}}$ & $\mathbf{T}_{\mathbf{2}}$ & $\mathbf{T}_{\mathbf{3}}$ & $\mathbf{T}_{\mathbf{4}}$ \\
\hline Wheat Flour (g) & 100.00 & 95.00 & 90.00 & 85.00 \\
\hline Jack fruit Rind flour (g) & 0.00 & 5.00 & 10.00 & 15.00 \\
\hline Fat (g) & 50.00 & 50.00 & 50.00 & 50.00 \\
\hline Sugar powder (g) & 50.00 & 50.00 & 50.00 & 50.00 \\
\hline Vanilla essence (m) & 0.50 & 0.50 & 0.50 & 0.50 \\
\hline Baking powder(g) & 0.50 & 0.50 & 0.50 & 0.50 \\
\hline Milk powder (g) & 15.00 & 15.00 & 15.00 & 15.00 \\
\hline Water (ml) & 30.00 & 30.00 & 30.00 & 30.00 \\
\hline Salt $(\mathbf{g})$ & 3.00 & 3.00 & 3.00 & 3.00 \\
\hline
\end{tabular}

Note:

$\mathrm{T}_{1}$ Sample $=100 \%$ wheat flour (control)

$\mathrm{T}_{2}$ Sample $=95 \%$ wheat flour and $5 \%$ jack fruit rind flour

$\mathrm{T}_{3}$ Sample $=90 \%$ wheat flour and $10 \%$ jack fruit rind flour

$\mathrm{T}_{4}$ sample $=85 \%$ wheat flour and $15 \%$ jack fruit rind flour

Table.2 Nutritional Composition of Wheat flour and Jack fruit rind flour were analysed using AOAC methods

\begin{tabular}{|l|l|l|l|}
\hline & Jack fruit rind flour & Wheat flour & Milk powder \\
\hline Moisture (\%) & $10.83 \pm 0.12$ & $13.32 \pm 0.03$ & $3.50 \pm 0.23$ \\
\hline Protein (\%) & $4.25 \pm 0.05$ & $11.00 \pm 0.83$ & $25.80 \pm 0.45$ \\
\hline Fat (\%) & $0.78 \pm 0.04$ & $0.9 \pm 0.05$ & $26.7 \pm 0.01$ \\
\hline Ash (\%) & $6.28 \pm 0.44$ & $0.60 \pm 0.01$ & $6.00 \pm 0.04$ \\
\hline Fiber (\%) & $10.10 \pm 1.24$ & $0.53 \pm 0.02$ & - \\
\hline Carbohydrates (\%) & $77.86 \pm 1.02$ & $74.18 \pm 1.84$ & $38.00 \pm 1.23$ \\
\hline Energy (Kcal) & $337.26 \pm 0.42$ & $348.00 \pm 0.43$ & $496 \pm 0.33$ \\
\hline
\end{tabular}


Table.3 Mean scores for the sensory evaluation of cookies samples

\begin{tabular}{|l|c|c|c|c|}
\hline Quality Parameters & $\mathbf{T}_{\mathbf{1}}$ & $\mathbf{T}_{\mathbf{2}}$ & $\mathbf{T}_{\mathbf{3}}$ & $\mathbf{T}_{\mathbf{4}}$ \\
\hline Colour & $7 \pm 0.37$ & $9 \pm 0.23$ & $8 \pm 0.46$ & $8 \pm 0.93$ \\
\hline Aroma & $8 \pm 0.23$ & $9 \pm 0.17$ & $7 \pm 0.15$ & $7 \pm 0.35$ \\
\hline Appearance & $8 \pm 0.15$ & $9 \pm 0.42$ & $9 \pm 0.50$ & $7 \pm 0.65$ \\
\hline Taste & $8 \pm 0.43$ & $9 \pm 0.23$ & $7 \pm 0.38$ & $7 \pm 0.27$ \\
\hline Texture & $8 \pm 0.61$ & $9 \pm 0.47$ & $8 \pm 0.17$ & $8 \pm 0.31$ \\
\hline Overall acceptability & $7 \pm 0.62$ & $9 \pm 0.54$ & $8 \pm 0.46$ & $8 \pm 0.31$ \\
\hline
\end{tabular}

Note:

$\mathrm{T}_{1}$ Sample $=100 \%$ wheat flour,

$\mathrm{T}_{2}$ Sample $=95 \%$ wheat flour, $5 \%$ jack fruit rind flour,

$\mathrm{T}_{3}$ Sample $=90 \%$ wheat flour, $10 \%$ jack fruit rind flour,

$\mathrm{T}_{4}=85 \%$ wheat flour, $15 \%$ jack fruit rind flour

Table.4 The effects of jackfruit rind powder in the weight, diameter, thickness, spread ratio on cookies

\begin{tabular}{|l|c|c|c|c|}
\hline Parameters & $\mathbf{T}_{\mathbf{1}}$ & $\mathbf{T}_{\mathbf{2}}$ & $\mathbf{T}_{\mathbf{3}}$ & $\mathbf{T}_{\mathbf{4}}$ \\
\hline Weight (g) & 10.70 & 11.10 & 11.12 & 11.42 \\
\hline Diameter(cm) & 3.50 & 3.20 & 3.35 & 3.48 \\
\hline Thickness(cm) & 0.60 & 0.70 & 0.78 & 0.92 \\
\hline Spread ratio (\%) & 583.33 & 457.14 & 429.48 & 378.26 \\
\hline
\end{tabular}

Note;

$\mathrm{T}_{1}$ Sample $=100 \%$ wheat flour,

$\mathrm{T}_{2}$ Sample $=95 \%$ wheat flour, $5 \%$ jack fruit rind flour,

$\mathrm{T}_{3}$ Sample $=90 \%$ wheat flour, $10 \%$ jack fruit rind flour,

$\mathrm{T}_{4}=85 \%$ wheat flour, $15 \%$ jack fruit rind flour

Fig.1 Flow chart of preparation of Jack fruit rind flour

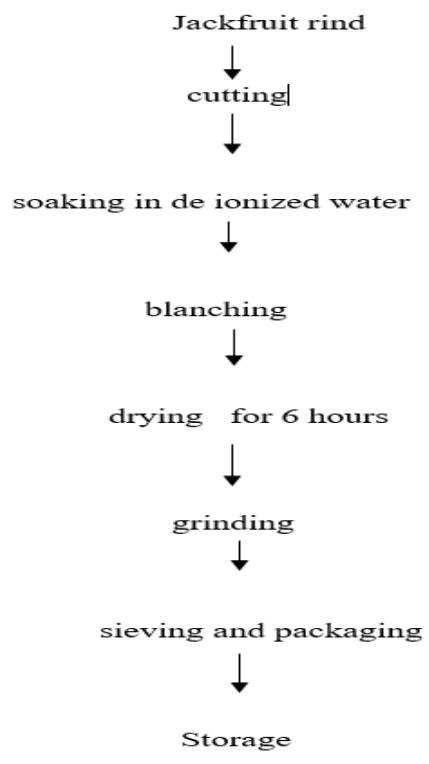


Fig.2 Schimatic flow diagram of preparation of cookies
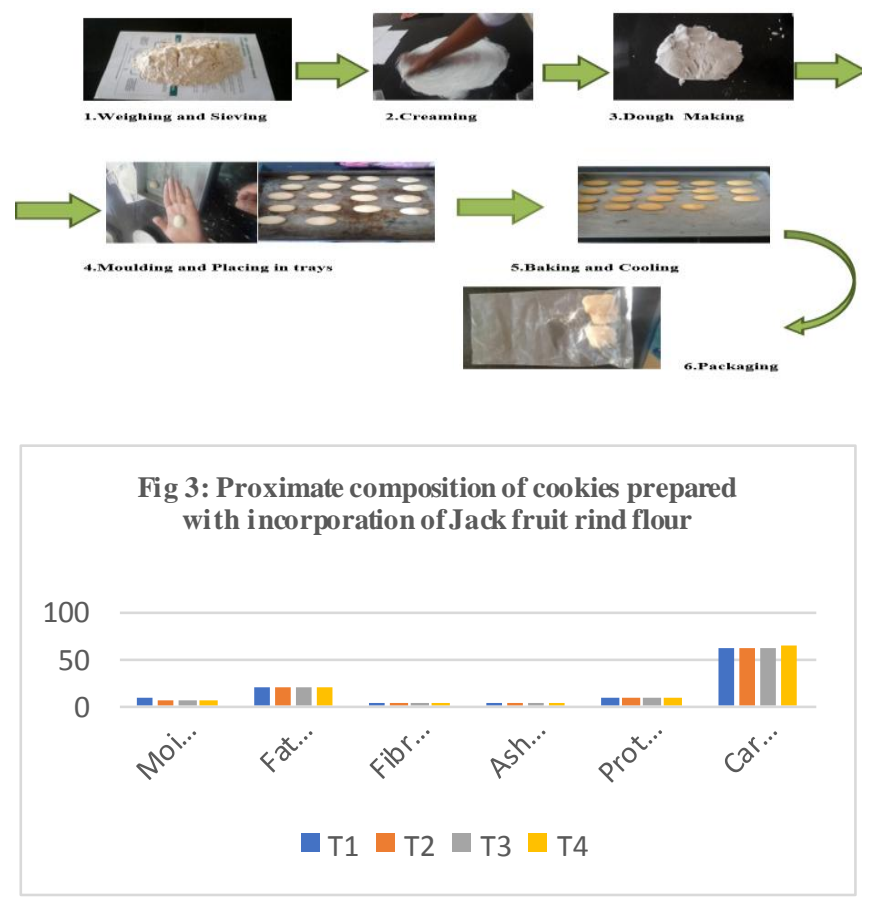

Proximate composition of cookies prepared with incorporation of Jack fruit Rind powder

Results revealed that substitution of JRF (5\%) significantly affected the proximate compositions of cookies. Moisture content in cookies decreases with the addition of substituted JRF. However, the highest moisture content $(8.72 \%)$ was found in sample $\mathrm{T}_{1}(0 \% \mathrm{JRF})$, whereas the lowest amount $(6.50 \%)$ was resulted in $\mathrm{T}_{4}$. Ash content in cookies also increased with the addition of JRF. Adhesiveness was not affected by addition of JRF into bread samples. In contrary, cohesiveness was significantly $(\mathrm{p}<0.05)$ affected by addition of JRF in composite breads. It decreased from 0.72 in BC to 0.54 in B15JRF (Felli et al, 2013).

The highest ash $(2.40 \%)$ were observed in sample $\mathrm{T}_{4}(15 \% \mathrm{JRF})$ and the lowest ash $(0.70 \%)$ a were found in control $\left(\mathrm{T}_{1}\right)$.
In this research, fat content and total carbohydrate in cookies were found to be decreased with the replacement of JRF (Table 2). Control sample contained highest fat content (21.21\%) and lowest total carbohydrate $(60.36 \%)$, whereas sample $\mathrm{T}_{4}$ resulted in lowest fat content $(19.02 \%)$ and higher total carbohydrate $(64.56 \%)$. Low fat and higher carbohydrate content of JRF might be possible reason behind the decreasing of fat and increasing of carbohydrate content in supplemented cookies. By addition of JRF there is increase in the fiber percentage in cookies is due to presence of high fiber in JRF. By addition of JRP into the formulation of bread samples, the TDF significantly ( $\mathrm{P}<$ 0.05 ) increased from $3.87 \%$ in BC to $11.39 \%$ in B15JRP (Reza Felli et al., 2018).

In conclusion the based on obtained results, the incorporation of JRF in different ratio caused significant influence on sensory and physico chemical attributes. By addition the level of JRF incorporated into WF, the darkness of cookies samples were 
significantly increased while their reduced spread ratio compared to the control. Cookies samples substituted with 5\% JRF had the highest mean scores of overall acceptances among samples. Therefore, this knowledge can be used to make commercial products. The introduction of such new technology, would increase overall economic, society health and well-being.

\section{References}

Abu, J.O., J.O. Icheikwura, E.K. Ingbian Replacement of wheat flour with cowpea starch concentrates: Effects on physical and sensory properties of biscuits and cakes. Int. J. of Food Science, Technology and Nutrition, 1 (1) (2007), pp. 31-38

Ade, I.C., Ingbian, E.K., Abu, J.O. 2012, Physical, Chemical and Sensory Properties of Baked Products from Blends of Wheat and African Yam Bean (Sphenostylis stenocarpa) Water-Extractable Proteins. Nigerian Food Journal Volume 30, Issue 1, 2012, Pages 109-115

Anu B, Khalid G, Charanjit SR. Functional and sensory properties of cookies prepared from wheat flour supplemented with cassava and water chestnut flours. Cogent Food Agric. 2015; 1: 1019815.

AOAC. Official methods of analysis of the Association of Official Analytical Chemists, 2010

Feili R, Zzaman W, Abdullah W N W and Yang T A. (2013). Physical and sensory analysis of high fiber bread incorporated with jackfruit rind flour. Food Science and Technology 1(2): 30-36. https://doi.org/10.13189/fst.2013.010203

Galisteo, M., Duarte, J. and Zarzuelo, A. 2008. Effects of dietary fibers on disturbances clustered in the metabolic syndrome. Journal of Nutritional Biochemistry 19: 71-75.

Haq, N. 2002. Improvement of Underutilized Fruits in Asia. Annual Report. Community Fund, UK.

Inbaraj, BS., Sulochana, N, Use of Jackfruit peel carbon (JPC) for adsorption of rhodamine - B, a basic dye from aqueous solution. Indian J. of Chem. Tech., 2006; (13): $17-23$.

Kamaliya, M. K. and Kamaliya, K.B. 2001. Baking Science and Industries. 1st Edn. Vol. I \& II.

Prakash O, Kumar R, Mishra A and Gupta R (2009). Artocarpus heterophyllus (Jackfruit): an overview. Pharmacognosy Reviews 3(6) 353-358.

Ranganna S. Handbook of analysis and quality control for fruit and vegetable products. Tata McGraw-Hill, New Delhi. 2016 RESEARCH NOTE J. Food Sci. Techol. Nepal, Vol. 9 (85-89), 2016 ISSN: 18160727

Reza Felli, Tajul Aris Yang, Wan Nadiah Wan Abdullah and Wahidu Zzaman. Effects of Incorporation of Jackfruit Rind Powder on Chemical and Functional Properties of Bread. Tropical Life Sciences Research, 29(1), 113-126, 2018

Rodriguez-Ambriz, S. L., Islas-Hernandez, J. J., Agama- Acevedo, E., Tovar, J., and BelloPerez, L A. 2008. Characterization of a fibre rich powder prepared by liquefaction of unripe banana flour. Food Chemistry, $107,1515-1521$

Schiraldi, A., and Fessas, D. (2000). Mechanism of staling. In C. Pavinee, Vodovotz, (eds). Bred Staling, New York: CRC Press, Inc. P. 2-10.

\section{How to cite this article:}

Ramya, H. N., S. Anitha and Ashwini, A. 2020. Nutritional and Sensory Evaluation of Jackfruit Rind Powder Incorporated with Cookies. Int.J.Curr.Microbiol.App.Sci. 9(11): 3305-3312. doi: https://doi.org/10.20546/ijcmas.2020.911.395 